\title{
Analysis of reproduction and spawning season of glass catfish Ompok hypophthalmus (Bleeker): case in lakes in Buluh Cina Village, Riau, Indonesia
}

\author{
Thamrin - Rindwan Manda Putra • Rahman Karnila • Nofrizal iD
}

Thamrin - RM Putra - R Karnila - Nofrizal (Corresponding author)

Department of Environmental Science, Graduate Program, Riau University and Fisheries and Marine Science Faculty, Riau University, Pekanbaru, Indonesia.

\author{
email: aan_fish@yahoo.com
}

Received: December 12, 2019 • Accepted: January 14, 2020 • Published Online: February 03, 2020

\begin{abstract}
The purpose of this research was to determine the reproductive system and fish spawning season (Ompok hypophthalmus) in Pinang Luar and Pinang Dalam Lakes in Buluh Cina Village of Kampar. This research was conducted at Oxbow Lake of Buluh Cina Village and the Ecology Laboratory of the Faculty of Fisheries and Marine Sciences, University of Riau. Sampling collection of O. hypophthalmus was carried out at Oxbow Lake (Pinang Dalam and Pinang Luar Lakes) of Buluh Cina from September to November 2016. Meanwhile, measurement of in situ water quality and data retrieval was carried out only on September 14, 2016. O. hypophthalmus is estimated to experience spawning only once a year. Spawning time or spawning of fish in November in 2016 was estimated to be exactly the time after the full moon in November before December. Glass catfish studied was not related to the rainy season which usually occurs in the same fish in the Kampar river, because that year coincided with the summer in those months. In recent years, there has been a lot of talk about global climate change which causes uncertain environmental and seasonal conditions. Erratic seasonal conditions have caused the rainy and dry seasons to be erratic. Every living creature, including fish, is strongly influenced by its environmental parameters, whether in the form of the season or the environmental conditions of its own environmental parameters. Although this research was only carried out in a short period of time, it was necessary to look at the influence of the environment on fish that was focused on glass catfish (O. hypophthalmus) at Oxbow Lake of Buluh Cina Kampar Protected Forest.
\end{abstract}

Keywords: glass catfish, Kampar river, O. Hypophthalmus, reproduction, spawning

\section{Introduction}

Oxbow can be said to be a small lake that is formed by a part of river flow, which is separated from the main river due to the direction of the river, which cuts the narrow land in the river that forms a half-circle or more at the conservation forest in Buluh Cina. Buluh Cina Kampar has an oxbow lake consisting of Pinang Luar and Pinang Dalam Lakes which is also often called as oxbow lake (Indonesian: Danau Tapak Kuda). The waters are one of the most potential fishing 47 grounds in the Kampar area. Most of the freshwater fish that fill Pekanbaru City region 48 come from these waters. One of the region's mainstay fish species is glass catfish ( $O$. hypophthaimus), which can be found either in fresh or in the form of smoked fish. A few years earlier, the $O$. hypophthaimus was the second-largest number of fish caught in these waters. However, due to fish species being hunted too much by the community, it began to experience a drastic decline in conditions and began to be difficult to obtain in Pinang Dalam and Pinang Luar lakes. This condition occurred because glass catfish is a type of freshwater fish that had a high nutritional and the taste of the meat was quite tasty. Moreover, glass catfish was classified as one of the first-class freshwater fish groups in fish trading (Pulungan et al 1985).

There are 18 species of fish that are always caught in Pinang Dalam and Pinang Luar Lakes. However, there are only three dominant fish species that are always caught by fishermen in these waters, namely minnows (Thynnichthys thynnoides) with an estimated percentage of $50 \%$, glass catfish (O. hypophthaimus) with an estimated percentage of $25 \%$, and Asian redtail catfish (Hemibagrus nemurus) with an estimated percentage of $20 \%$ of the fishing catches. Glass catfish (Siluridae) is one type of freshwater fish that has important economic value in Riau. This condition occurred around two years ago when the fish (O. hypophthalmus) was difficult to obtain. If the price of this fish was previously in the range between USD $4.65-5.35 / \mathrm{kg}$, at that time, it was in the range between USD $6.43-7.14 / \mathrm{kg}$. On the other hand, its price in dry condition (smoked fish) was around Rp. 14.28/kg. 
Meanwhile, the price of these fish in neighboring Malaysia ranges between RM 200-250 (USD 48.04 - 60.05).

Currently, glass catfish (O. hypophthalmus) has been successfully bred by artificial methods. However, glass catfish that are found in the market in general still come from catches in nature. The main catchment areas for glass catfish as mentioned above are from the waters of Pinang Dalam and Pinang Luar Lake. This oxbow was previously surrounded by conservation forests, as a supplier of the sustainability of the lake's water resources when it was cut off from Kampar River. However, lately, the conservation forest of Buluh Cina Kampar, which has become the pride of Riau region, has turned into an oil palm plantation.

In addition, fishing activities of the glass catfish $(O$. hypophthalmus) continues to be carried out without any control from any party. This condition, among others, is caused by its taste, which is relatively good, which causes the price to be quite expensive. If this condition is left unchecked and the fish catching continues, especially if fishing is conducted before the mature fish experiences spawning, it will accelerate the decline in the abundance of fish in the waters. Research on the reproduction of fish has been carried out by several researchers, but the exact time of spawning has not been fully understood. Another factor that is also interesting is the condition of the lake in the form of oxbow lake, which supplies water primarily from the original river. It experiences flooding during the rainy season and there is a lack of water that causes it to separate from Kampar River as one of its water suppliers during the dry season.

This condition will cause fluctuations in water quality parameters, such as $\mathrm{pH}$ when the flood season becomes high. In addition, the water becomes more acidic or the $\mathrm{pH}$ value decreases due to the main source of water comes only from the surrounding peatlands during the dry season. In recent years, there has been a lot of talk about global climate change, which causes uncertain environmental and seasonal conditions. Erratic seasonal conditions have caused the rainy and dry seasons to be erratic. Every living creature, including fish, is strongly influenced by its environmental parameters, whether in the form of the season or the environmental conditions of its own environmental parameters. Although this research was only carried out in a short period, it was necessary to look at the influence of the environment on fish that was focused on glass catfish (O. hypophthalmus) at oxbow in Buluh Cina Kampar Protected Forest. The purpose of this research was to determine the reproductive system and fish spawning season (O. hypophthalmus) in Pinang Luar and Pinang Dalam Lakes in Buluh Cina Village of Kampar.

\section{Materials and Methods}

This research was conducted at Oxbow Lake of Buluh Cina Village (Figure 1) and the Ecology Laboratory of the
Faculty of Fisheries and Marine Sciences, University of Riau. Sampling collection of glass catfish was carried out at Oxbow Lake (Pinang Dalam and Pinang Luar Lakes) of Buluh Cina from September to November 2016. Meanwhile, measurement of in situ water quality and data retrieval was carried out only on September 14, 2016. This research used a survey method, both for the $O$. hypophthalmus bioecology and for the long-weight relationship, eating habits, and fish gonad maturity level. The number of fish used was 166, and the observed water quality parameters consisted of 4 categories, namely water surface temperature, water surface $\mathrm{pH}$, dissolved oxygen (DO) and water brightness. To find out the overall quality of water from all lakes, 9 sampling points were determined, namely: (1) Station I of Pinang Luar lake, on the outer door which was measured at 08:20; (2) Station II of Pinang Luar lake, which was estuary of Pinang Dalam river that was measured at around 08:20; (3) Station III of Pinang Luar Lake which vas measured around 08:40; (4) Station IV of Pinang Luar Lake, on the outer door of Rawang which was measured around 09:00; (5) Station V of Pinang Luar Lake, on the outer door of Semilang River which was measured around 09:20 (6) Station VI of Pinang Luar lake, on the outer door of Salam River which was measured around 09:40 (7) Station VII of Pinang Luar lake, on the outer door of Tusam Panjang River which was measured around 10:00 (8) Station VIII of Pinang Dalam Lake, on the outer door of Tanah Biliang River, which was measured around 10:20; and (9) Station IX which was in the middle of the deep waters of Pinang Lake, in front of the outer door of Tanah Biliang River, which was measured around 10:40. The instrument used in this research included a thermometer to measure the surface temperature of the water, hand made sechii disk to measure the brightness of the waters, Whatman Standard $\mathrm{pH}$ (Water Proof pH (AMT03), Qingdao, China) to measure the $\mathrm{pH}$ of the waters and a portable test kit to measure dissolved oxygen in the was measured by waters by Waterproof Portable Dissolved Oxygen Meter and BOD Meter - HI98193, Hanna Instruments, Slovenia). Other equipment consisted of a digital decimal scale to measure the weight of fish samples, rollers to measure the standard length and the total length of the sample fish, cutter to dissect the sample fish, luv glass to observe the type of food and the development of gonads, and digital cameras for documentation.

\section{Data collection}

\section{Reproductive Biology}

Observation of $O$. Hyphopthalmus reproduction biology was carried out including the development of gonads morphologically, the size of mature fish gonad, spawning season and those related to environmental conditions, diameters of mature gonad eggs. 


\section{Gonad development}

The development of gonads was studied based on the level of gonad maturity focused only on morphological observations. Observation of gonad levels of female and male fish was analyzed based on Chinabut et al (1991).

\section{Gonad Maturity Index}

Gonad Maturity Index of fish was analyzed by using the formula as follows, Gonad Maturity Index $=\mathrm{Bg} / \mathrm{BT}$ x 100 , which Gonad Maturity Index (\%), Bg is gonad weight, and $\mathrm{Bt}$ is body weight.

\section{Egg Diameter}

The size of the egg diameter was observed using a sample system, which first divided each ovary into 3 subsets (anterior, middle and posterior). From each sample, then samples were taken for observation of egg diameter that was measured using an ocular micrometer on a microscope.

Data analysis
The data was analyzed using the following steps: (1) Development of gonads morphologically and male and female sex ratio were analyzed using their characteristics. (2) The size of the mature fish gonad of glass catfish was analyzed using data on the level of gonad maturity associated with the size data of the sample fish, both male and female. (3) The fish breeding spawning season was analyzed using gonad maturity data and gonad maturity index, associated with the sampling location during the four months of sampling. (4) The spawning pattern of the fish was analyzed using the characteristics of gonad maturity level, gonad maturity index, glass catfish egg diameter of the mature gonad. (5) The size of the egg diameter for each sub-sampling between the anterior, middle and posterior ovaries was tested with Mann-Whitney using the Excel program. (6) To analyze the relationship between fecundity and length of fish, we used the standard size and bodyweight of fish by using a regression-correlation relationship with Excel. The standard size was used because the tail end of the sample was damaged so much that it was doubtful. If this data was doubtful, then the data bias was high.

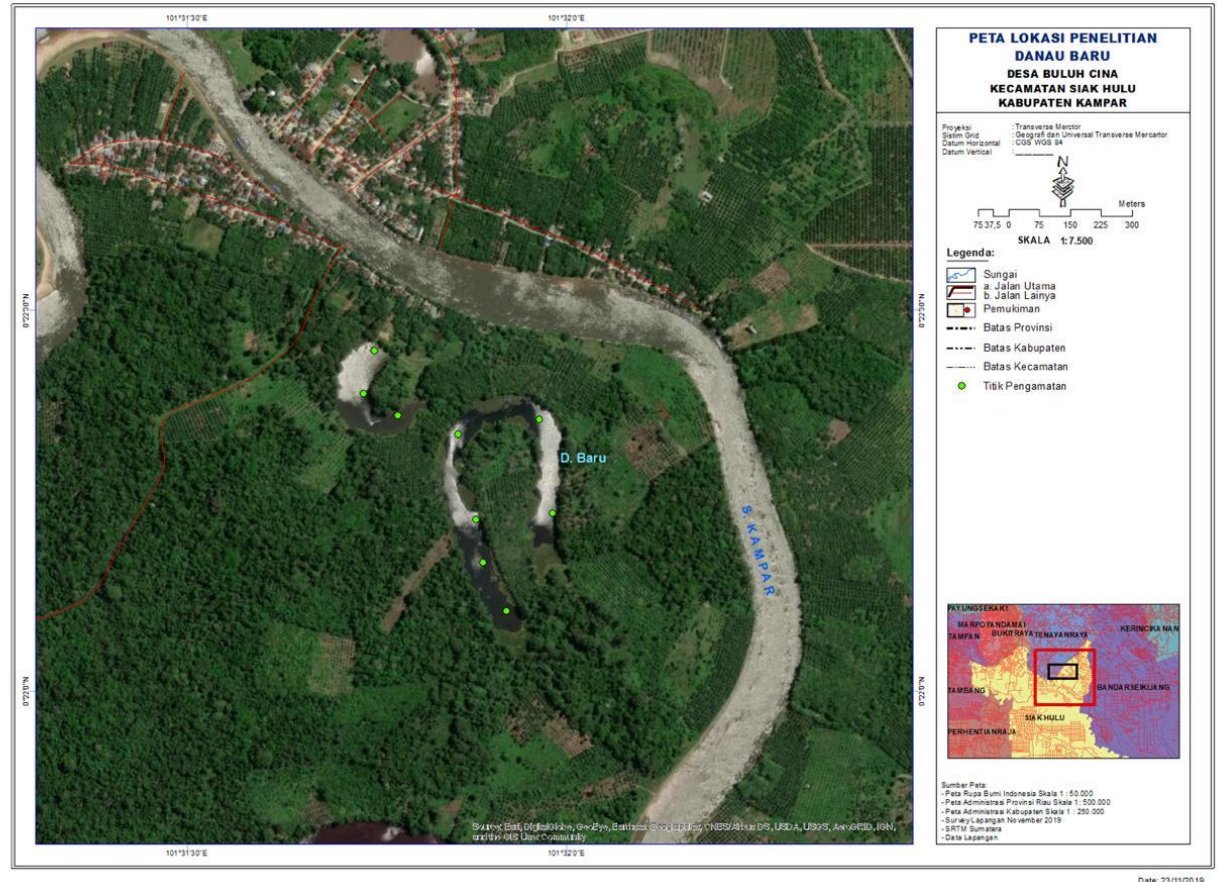

Figure 1 Map of the Oxbow Lake of Buluh Cina village as research location for sampling point.

\section{Results and Discussion}

\section{General conditions of research locations}

Oxbow of Buluh Cina village is also called as "Lake (Indonesian: Danau)" by the people of Buluh Cina Village. Overall, it consists of seven lakes. However, at the time of the flood, can only be divided into two lakes, namely Pinang Luar lake and Pinang Dalam lake. To maintain the sustainability of lake water availability, there are seven rivers flowing into the lake. Meanwhile, to ensure the overall availability of water for both lakes and rivers, there are 1000 hectares of forest that surrounds the entire lake. The forest is known as the Buluh Cina conservation forest. Even though it is a protected forest currently, it is estimated that around 15 hectares of the forest are undergoing conversion to plantations. Pinang Luar Lake and Pinang Dalam Lake in this area contained abundant fish before five years ago. Thus, the local community also calls them "Danau Silansai Hutang (English: debt repayment 
lake)", which has the implication that if the community has a debt, it will be able to be paid off in a short time by catching fish in both lakes. Type of fish commonly caught by local fishermen includes walago, redtail catfish, glass catfish, snake head, arowana, perch-likes, gourami, catfishes, ell, minnows, etc. The largest number of catches comes from minnows species with an estimated percentage of $50 \%$, followed glass catfish (25\%), Asian redtail catfish (20\%), and others (5\%).

\section{Water Quality}

The main water parameters observed from 3 stations, the research conducted obtained data that can be seen in table 1 .

Table 1 Average temperature, brightness, DO and $\mathrm{pH}$ of Oxbow Lake of Buluh Cina Village, Kampar. Water parameter of Temperature and $\mathrm{pH}$ were measured by (Water Proof $\mathrm{pH} /$ Orp / Conductivity / Tds / Salt / Temp Meter (AMT03), Qingdao, China). Disolved oxigent (DO) was measured by Waterproof Portable Dissolved Oxygen Meter and BOD Meter - HI98193, Hanna Instruments, Slovenia. Waters depth was measured by echo sounder, Knudsen, Sounder 1612, Canada and the water brightness was measured by hand made secchi disk.

\begin{tabular}{cccccc}
\hline $\mathrm{N}^{\circ}$ & $\begin{array}{c}\text { Temperature } \\
\left({ }^{\circ} \mathrm{C}\right)\end{array}$ & $\begin{array}{c}\text { Brightness } \\
(\mathrm{cm})\end{array}$ & $\begin{array}{c}\text { Depth } \\
(\mathrm{cm})\end{array}$ & $\begin{array}{c}\mathrm{DO} \\
(\mathrm{mg} / \mathrm{l})\end{array}$ & $\mathrm{pH}$ \\
\hline 1 & 30.9 & 50 & 90 & 0.30 & 7.3 \\
2 & 32.2 & 35 & 120 & 1.40 & 6.3 \\
3 & 32.2 & 35 & $>200$ & 0.54 & 6.0 \\
\hline \multicolumn{5}{c}{ Note: DO is dissolved of oxygen and $\mathrm{pH}$ is power of hydrogen }
\end{tabular}

From Table 1, it can be seen that the waters of the Pinang Luar Lake and Pinang Dalam Lake were classified as acidic because the $\mathrm{pH}$ in the entire research station was below 7, which was 6.0 in Pinang Dalam Lake and 6.3 in Pinang Luar Lake. While, the face part of Pinang Luar Lake, which was close to Kampar river water, it had a pH of 7.3 or relatively normal. The lowest dissolved oxygen was found at Station I, followed by Station III (0.54) and the highest was Station II (1.40). The depth of the water was also different between the three observation stations: at Station I, it was only $90 \mathrm{~cm}$; at Station II, it had a depth of $120 \mathrm{~cm}$; while Station III had a depth of more than $200 \mathrm{~cm}$. Other parameters that were important in this research were surface temperature and water brightness. Observation results obtained $30.9{ }^{\circ} \mathrm{C}$ at Station I, and $32.2{ }^{\circ} \mathrm{C}$ for Station II and Station III. While the highest brightness was found at Station I with a brightness of $50 \mathrm{~cm}$, while the brightness at Station II and III in Pinang Luar and Pinang Dalam Lake was $35 \mathrm{~cm}$.

\section{Gonad maturity}

All of the samples (166 fish) observed, only dozens of samples had gonads, both from the testes group and from the oocyte group. Male fish began to produce sperm starting from a length of $16.7 \mathrm{~cm}$ with a weight of 18.7 grams. While female fish began producing oocytes starting from a standard length of $15.8 \mathrm{~cm}$, a total length of $18.3 \mathrm{~cm}$ with a weight of 13.00 grams. It was estimated that it was not related to the size of the smaller sample fish. Because even though the sample size in this research began in the length of $17.0 \mathrm{~cm}$, most of them were in a mature size range in reproduction, as stated by Elvyra et al (2008) that the smallest size of female $O$. hypophthalmus reached mature gonad at a size of $22.9 \mathrm{~cm}$, while male was at $22.6 \mathrm{~cm}$ (length). This research used a sample size of fish between $17.0 \mathrm{~cm}$ to $32.7 \mathrm{~cm}$. Observation of the maturity level of $O$. hypophthalmus fish was classified into five stages, namely gonad maturity level I (undeveloped), II (early development), III (developing), IV (mature) and V (post-spawning) both in female and male fish which referred to modification of Cassie (Effendi 1992) and Chinabut et al (1991). The level of comparison between male and female fish with a ratio of $1: 1.25$, (male: female).

From the results of the research, it was shown that glass catfish oogenesis from gonad maturity level I to gonad maturity level $\mathrm{V}$ experienced changes both in terms of ovary size and in terms of color, as well as the size and nature of egg grains. At the initial stage, it was small in pink, then along with the change in its gonad maturity level, the color condition also changed to a deep red or blackish red (gonad maturity level II and III). At gonad maturity level IV or when the oocyte was mature, it had a uniform yellow color. At this gonad maturity level, eggs could also be clearly seen with the eyes and could be easily separated from the group. After experiencing spawning, the remaining ovaries changed color to pale, and eggs that were in the condition of gonad maturity level IV were still tightly arranged and changed into a rare arrangement. Elvyra et al (2008) stated that $O$. hypophthalmus of Kampar River 36 had one spawning season and it occurred from September to November. In this research, 37 the probability of occurring was somewhat different and was estimated to end towards 38 mid-December because on the $14^{\text {th }}$ of December the sampling time was still found the 39 remnants of the testicles from some of the sample fish which indicated spawning had just ended. The existence of the substance when the surface of the flood waters which wet the dry terrain after the dry season was a trigger for the spawning process, it 43 was stated by Van der Wall (2006) that may be, spawning season would be missed 44 because the rainy season has begun for quite a long time. In this research, it was estimated that the spawning time of glass catfish ended in midDecember. The difference in the results of spawning time obtained by Elvyra et al (2008) that O. hypophthalmus of Kampar River occurred in September to November may be due to erratic seasonal changes. The effect of water temperature, $\mathrm{pH}$ and DO was very small because both studies showed that the spawning season for fishes occurred during the flood season. 
Table 2 Criteria for assessing the maturity level of Selais fish oocytes.

\begin{tabular}{ll}
\hline Gonad maturity level & The ovary is in the form of two small pockets, filling about $1 / 8$ of the abdominal cavity. The surface \\
\hline I & of the ovary is slippery and pink. \\
(undeveloped) & The size of the ovary is larger than TKG I and fills in around $1 / 6$ of the abdominal cavity. The ovary \\
II & is dark red, and the egg is not clearly visible with the eyes. \\
(early development) & The ovary is red to black, filling $1 / 3-1 / 2$ of the abdominal cavity. The egg grains are visible with the \\
III & eyes, arranged in series and cannot be separated. \\
(developing) & The ovary has a yellow color, filling about $2 / 3$ of the abdominal cavity. The eggs are yellow and \\
IV & arranged densely, and the eggs are easily separated. \\
(mature) & The ovary fills around $1 / 4$ the abdominal cavity and is slightly. Wrinkled. The ovary is pale, and the \\
V & grains are arranged rarely. \\
(post-spawning) &
\end{tabular}

The implementation of this research has been carried out starting on September 2, 2016, but due to the difficulty of obtaining samples that were in accordance with the size of the fishes that have reproduced; the gametogenesis data was only available from sampling on October 17, 2016. The development of the gonad of the fishes was presented from October 17 - November 2016.

Figure 2 shows that glass catfish ovary obtained on October 17, had gonad maturity level II and III. From the two gonad maturity levels contained the fish, it can be compared that $40 \%$ contained gonad maturity level II and $60 \%$ contained TKG III.

Figure 3 shows that the fish obtained on October 17, 2016, still had two levels of gonad maturity, namely gonad maturity level II and gonad maturity level III. Meanwhile, if seen from the size distribution, oocytes in gonad maturity level II have been dominated by the size of 08 with a number of about $50 \%$. Then the egg size distribution for gonad maturity level III has been dominated by oocyte size of 0.9 microns, with a number of about $45 \%$.

Figure 4 and 5 shows that in October $27^{\text {th }}$ sampling, it found two gonad maturity levels, namely gonad maturity level II and III (Figure 6). Gonad maturity level II had the highest number of eggs at about 0.9 micron (40\%), while at gonad maturity level III (Figure 4 ) found the highest number of sizes of 1.1 microns mesh size with a number of $(60 \%)$. This condition shows that oogenesis was moving from gonad maturity level II to III.

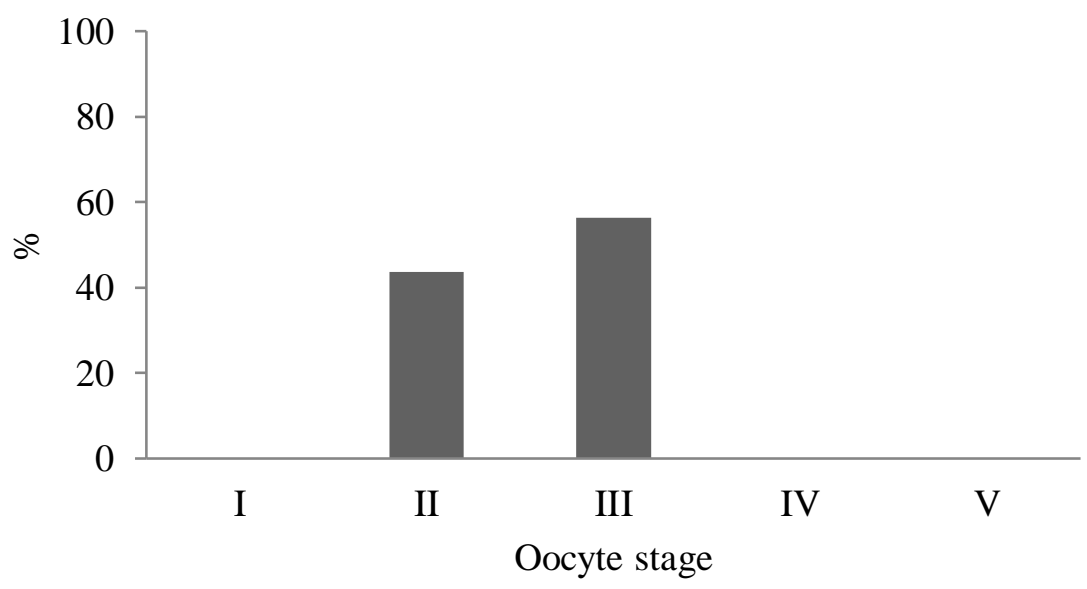

Figure 2 Level of oocyte gonad maturity of O. hypophthalmus found on sample of October 17, 2016. 


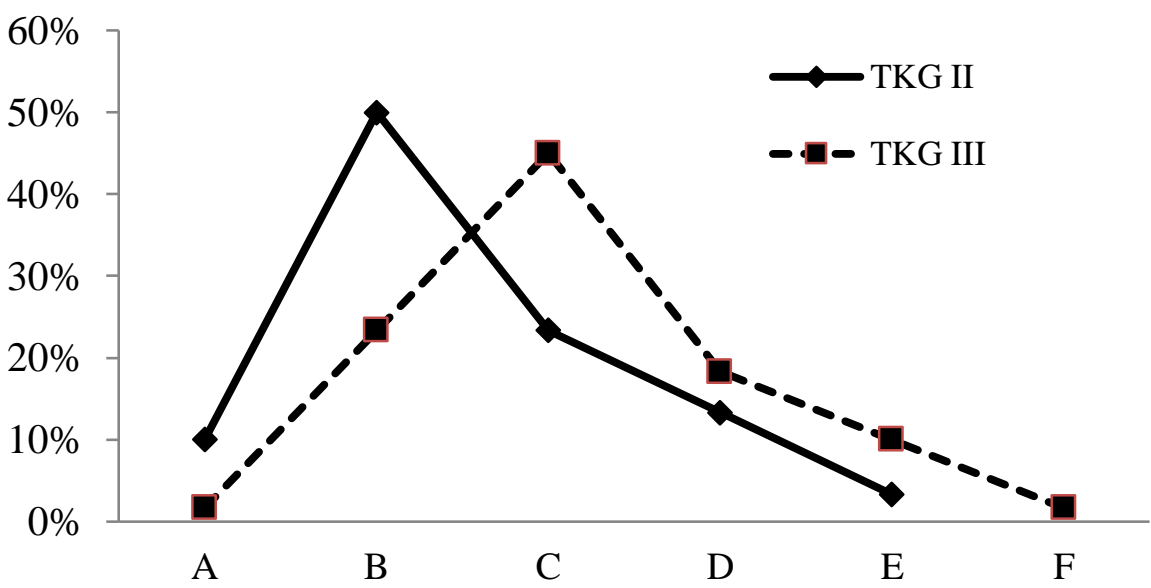

Egg diameter

Figure 3 Gonad maturity levels of O. hypophthalmus from sample of October 17, 2016.

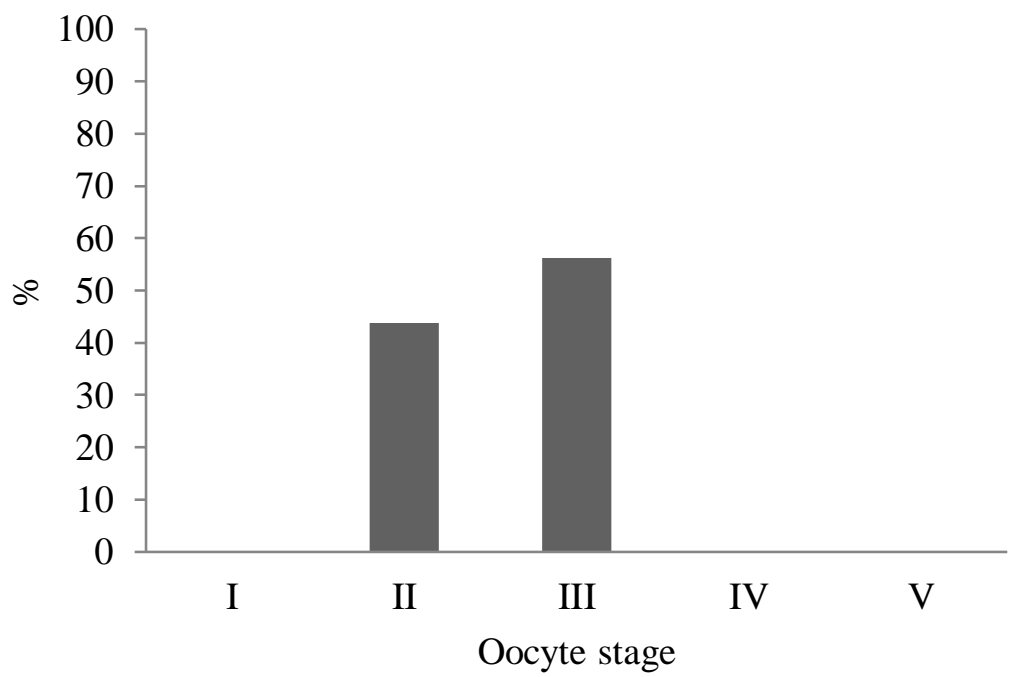

Figure 4 Presence of each of $O$. hypophthalmus oocyte stages on October 27, 2016.

Figure 7 shows that glass catfish obtained on November 12, 2016, only had one level of gonad maturity, namely the maturity level of gonad III. While the Oocyte size distribution at gonad maturity level III had the highest number of oocytes in 1 micron, with the smallest to the largest size classified as normal (Figure 6). It was done in the morning. On the other hand, on the other two sides, it was done during the day when the sun was hot. However, relating to this parameter did not limit the life of fish in these waters because fish can tolerate temperatures in the $\mathrm{pH}$ range of 6.5-9.0 in general (Boyd 1982). For water brightness, the outer side adjacent to the river was higher compared to the two sides inside, namely Station II and III. This condition was caused by the influence of the surrounding swamp water on Station II and III. This condition was not only more turbid but also more acidic which caused a lower $\mathrm{pH}$. However, the $\mathrm{pH}$ of the waters was basically always changing at all times (Mulyanto 1992). Meanwhile, on the side adjacent so with the Kampar Riverside was clearer because the dissolved particles from the swamp were thought to partially settle at Station II and III with relatively calm water conditions, also due to the influence of the seepage of Kampar River towards Station I. 


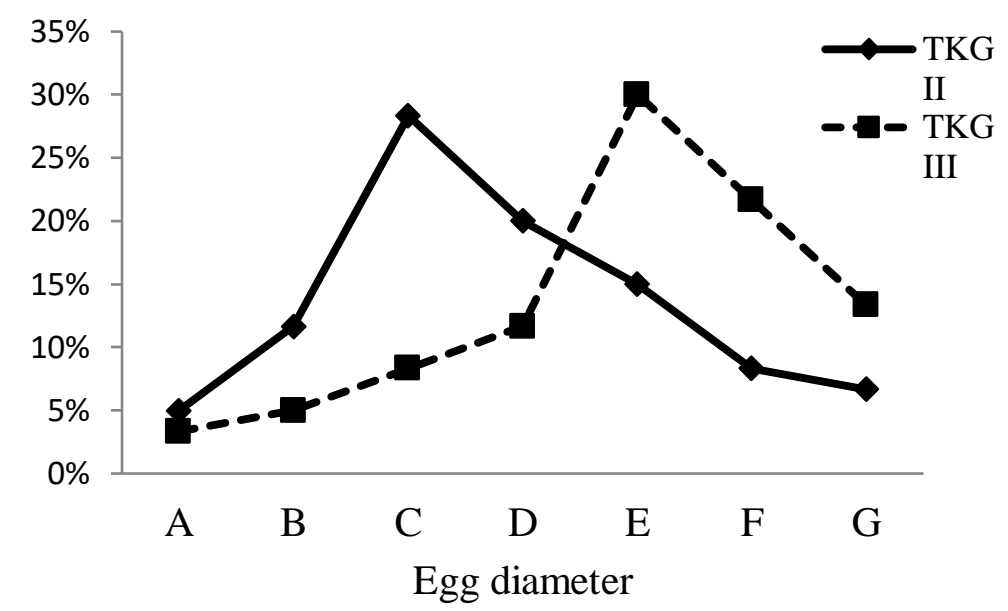

Figure 5 The gonad maturity level O. hypophthalmus from a sample of October 27, 2016.

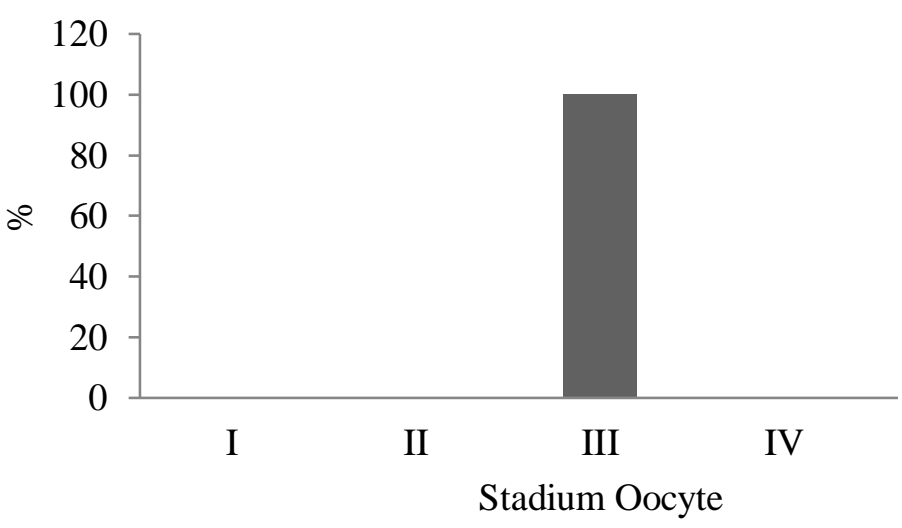

Figure 6 Condition of $O$. hypophthalmus eggs on sample of November 2, 2016.

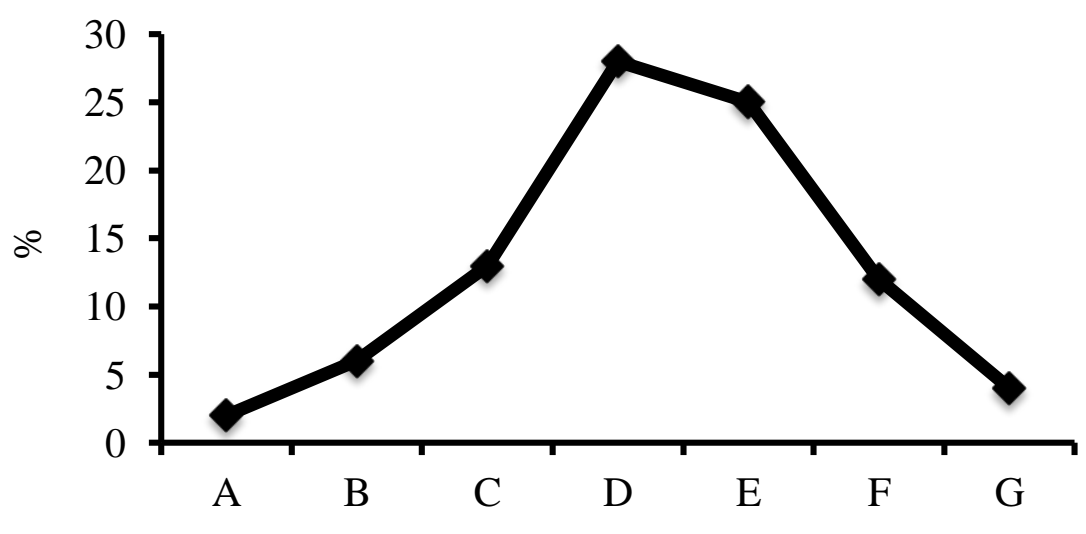

Egg diameter

Figure 7 The gonad maturity level for $O$. hypophthalmus from a sample of November 2, 2016. 
The lowest dissolved oxygen (DO) was found at Station I (0.30), followed by Station III (0.54) and the highest was found in Station 11(1.40). The low DO at Station I was likely due to the very shallow waters and also the measurement time in the morning. While, the condition of the water in Station II flew a little and the time for taking the data was in the late afternoon. While at Station III, it was likely due to the high organic matter around it that came from trees and the leaves of the surrounding forest trees. Most of the trees were cut which led into the waters in order to convert the surrounding forest into oil palm plantations. Observation of glass catfish gametes was conducted only from September to November for the meantime, it can be concluded that glass catfish did the spawning completely, not in a partial form. This was based on the observation of gonad maturity level which only found only one stage at most in sampling. During the research, there were never more than two oocyte stages found as reported by Elvyra (2009), where she informed that in every sampling, she found up to 4 oocyte stages in one glass catfish ovary. Even in this research, the sampling in November only found one oocyte and testicular gonad maturity level.

The sample fish, namely only Stage IV for oocytes and testes. From the observation, it can be concluded that glass catfish was not partial in spawning, since the sample on November 14, 2016 only had one stage of oocytes (stage IV). This condition was also different from the results of research on the Kampar River conducted by Elvyra (2009), where the sample of fish in November was informed to be containing 3 oocyte stages, namely stages II, III and IV. The cause of the difference between the two results of the research was estimated to be two different locations of research, where this research was carried out in lake waters with relatively calm water conditions and in rivers that had flowing water. Other causes were likely to be due to changes in seasons from year to year.

The results of this research indicated that glass catfish spawning occurred around the end of November or at the beginning of December 2016. The results of spawning showed a different time with the results of Elvyra (2009) research of the same fish from the Kampar river, which found that glass catfish in Kampar river had a period of spawning around September 2009, The difference in spawning time of the two studies was also likely due to the shifting time of the rainy season from year to year, because the spawning time of fish was also affected by the rainy season. Most tropical fish are breeding in the rainy season (Munro 1990 Vazzoler and Menezes 1992; Alkins-Koo 2000); and only a few do breeding during the dry season (Wang et al 1995; Pusey et al 2002; Torres-Mejia and Ramirez-Pinilla 2008), or do so throughout the year (Alkins-Koo 2000).

\section{Conclusions}

O. hypophthalmus is estimated to experience spawning only once a year. Spawning time or spawning of fish in November in 2016 was estimated to be exactly the time after the full moon in November before December. Glass catfish studied was not related to the rainy season which usually occurs in the same fish in the Kampar River, because that year coincided with the summer in those months. Since this research was carried out only for a short period of time, it is recommended to conduct research at least within a period of one year (sampling) in order to get more detailed information.

\section{Acknowledgments}

Acknowledgments are expressed to the staff of Fisheries and Marine Sciences Faculty, Riau University who has helped carry out this research. Special thank also for Research and community service institution, Riau University that has provided funding support.

\section{Conflict of Interest}

The author declare no conflict of interest.

\section{References}

Alkins-Koo M (2000) Reproductive timing of fishes in a tropical intermittent stream. Environmental Biology of Fishes 571:49-66.

Boyd CE (1982) Water Quality Management In Fish Pond Culture Research And Development. Series No. 22. International Centre for Aquaculture, Aquaculture Experiment Station. Auburn University. Auburn.

Chinabut S, Limsuwan C, Kitsawat P (1991) Histology of the walking catfish, Clarias batrachus. International Development Research Centre.

Mulyanto (1992) Life environmental for fish. Departement of Education and Culture. (in Indonesia).

Elvyra RDD, Solihin R, Affandi Z, Junior (2008) Study on aspect of the glass catfish, Ompok hypophthalmus in Kampar River, Langgam District, Pelalawan Regency, Riau Province. Jurnal Natur Indonesia 122:117-123.

Elvyra R (2009) Study on genetic diversity and biology reproduction of glass catfish Ompok hypophthalmus in Kampar River. (Dissertation). Bogor (ID): Bogor Agricultural University.

Munro AD (1990) Tropical freshwater fishes. In: Munro ADA, Scott P, Lam TJ (Eds) Reproductive Seasonality in Teleosts: Environmental Influences. Boca Raton, CRC Press.

Ohta S, Effendi S (1992) Ultisols of "lowland Dipterocarp forest" in East Kalimantan, Indonesia: II. Status of carbon, nitrogen, and phosphorus. Soil science and plant nutrition 38:207-216.

Pulungan CP (1985) Morphometric of the glass catfish Ompok hypophthalmus from Kampar Kiri waters, Kampar Regency, Riau Province. Research Center of Riau University. Pekanbaru. (unpublished). 
Pusey BJAH, Arthington PG, Close Bird JR (2002) Larval fishes in rainforest streams: recruitment and microhabitat use. Proceedings of the Royal Society of Queensland110:27-46.

Torres-Mejia M, Ramirez-Pinilla MP (2008) Dry-season breeding of a characin in a Neotropical mountain river. Copeia 21:99-104.

Utomo M, Frye WW, Blevins RL (1990) Sustaining soil nitrogen for corn using hairy vetch cover crop. Agronomy Journal 82:979-983.

Van der Wall BCW (2006) Observations on the breeding habits of Clarias gariepinus (Burchell). Journal of Fish Biology 6:23-27.
Vazzoler AEAM, Menezes NA (1992) Síntese de conhecimento sobre o comportamento reprodutivo dos Characiformes da América do Sul (Teleostei: Characiformes). Revista Brasileira de Biologia $52: 627-540$.

Wang JTM, Liu C, Fang LS (1995) The reproductive biology of an endemic cyprinid, Zacco pachycephalus, in Taiwan. Environmental Biology of Fishes 43:135-143.

Weber M, De Beaufort LF (1913) The fishes of the Indo-Australian. Arch. II Malacopterygii, Myctophoidea, Ostariophysi: I. Siluroidea. Leiden: E. Brui. 